\title{
Characterization of $\beta-N$-acetylhexosaminidase (LeHex20A), a member of glycoside hydrolase family 20, from Lentinula edodes (shiitake mushroom)
}

\author{
Naotake Konno*, Hideyuki Takahashi, Masahiro Nakajima, Takumi Takeda and Yuichi Sakamoto
}

\begin{abstract}
We purified and cloned a $\beta$ - $N$-acetylhexosaminidase, LeHex20A, with a molecular mass of $79 \mathrm{kDa}$ from the fruiting body of Lentinula edodes (shiitake mushroom). The gene lehex20a gene had 1,659 nucleotides, encoding 553 amino acid residues. Sequence analysis indicated that LeHex20A belongs to glycoside hydrolase (GH) family 20, and homologues of lehex20a are broadly represented in the genomes of basidiomycetes. Purified LeHex20A hydrolyzed the terminal monosaccharide residues of $\beta$ - $N$-acetylgalactosaminides and $\beta$ - $N$-acetylglucosaminides, indicating that LeHex20A is a $\beta$ - $N$-acetylhexosaminidase classified into EC 3.2.1.52. The maximum LeHex20A activity was observed at $\mathrm{pH} 4.0$ and $50^{\circ} \mathrm{C}$. The kinetic constants were estimated using chitooligosaccharides with degree of polymerization 2-6. GH2O $\beta$-N-acetylhexosaminidases generally prefer chitobiose among natural substrates. However, LeHex20A had the highest catalytic efficiency $\left(k_{\text {cat }} / K_{m}\right)$ for chitotetraose, and the $K_{m}$ values for $G_{c} \mathrm{CNAc}_{6}$ were 3.9-fold lower than for chitobiose. Furthermore, the enzyme partially hydrolyzed amorphous chitin polymers. These results indicate that LeHex20A can produce $\mathrm{N}$-acetylglucosamine from long-chain chitomaterials.
\end{abstract}

Keywords: $\beta$-N-acetylglucosaminide, Chitin, Fungal cell wall, Glycoside hydrolase family 20, Basidiomycete

\section{Introduction}

Chitin, composed of $\beta-1,4$ linked $N$-acetylglucosamine (GlcNAc) units, is mainly found in crustaceans, insects and fungi. Enzymatic degradation of chitin is catalyzed by a two-component chitinolytic enzyme system. One component is chitinases (EC 3.2.1.14), which hydrolyze $\beta-1,4$ linkages in chitin polymers, endolytically producing chitooligosaccharides, especially chitobiose (Brurberg et al. 1996; Tanaka et al. 2001). The other is $\beta$ - $N$-acetylhexosaminidases (EC 3.2.1.52), which typically have no activity against chitin polymers, and instead degrade chitooligosaccharides formed by chitinases into monomers. Because the enzymes prefer short $\beta-N$-acetylglucosaminide substrates, chitobiose and p-nitrophenyl- $N$-acetyl- $\beta$-D-glucosaminide (pNP-GlcNAc), they are also called chitobiases (Drouillard et al. 1997; Tews et al. 1996). $\beta-N$ -

\footnotetext{
* Correspondence: naotake-k@ibrc.or.jp

Iwate Biotechnology Research Center, 22-174-4 Narita, Kitakami-shi, Iwate 024-0003, Japan
}

acetylhexosaminidases are widely distributed in animal tissues (Korneluk et al. 1986), insects (Hogenkamp et al. 2008; Yang et al. 2008), plants (Meli et al. 2010), bacteria (Clarke et al. 1995; Mark et al. 2001) and fungi (Cannon et al. 1994; López-Mondéjar et al. 2009; Jones and Kosman 1980), and belong to glycoside hydrolase (GH) families 3, 20 and 84 as categorized in the CAZy database (http:// www.cazy.org/index.html). The GH20 enzymes hydrolyze nonreducing terminal monosaccharide residues of $\beta-N$ acetylgalactosaminides and $\beta-N$-acetylglucosaminides.

In fungi, chitin is a main cell-wall component, together with $\beta$-glucans (Iten and Matile 1970; Vetter 2007), and most filamentous fungi such as ascomycetes and basidiomycetes produce chitinolytic enzymes. Some mycoparasitic fungi such as Trichoderma species produce extracellular chitinolytic enzymes for degradation of host cell walls during their mycoparasitic attack (Carsolio et al. 1994; Peterbauer et al. 1996; Seidl et al. 2006). On the other hand, some fungal chitinolytic enzymes act on their own cell walls during changes in

\section{穴}


morphology, which are an essential process in the fungal cell cycle (Mitchell and Sabar 1966; Seiler and Plamann 2003). For example, some chitinases (Rast et al. 1991; Shin et al. 2009) and $\beta$ - $N$-acetylhexosaminidases (Cannon et al. 1994; Kim et al. 2002) from filamentous fungi such as Aspergillus and Mucor species are suggested to have roles in processes such as hyphal autolysis, growth and branching. However, little information is known about the physiological function and role of fungal chitinolytic enzymes. Moreover, there have been no reports of cloned and characterized chitinolytic enzymes from basidiomycetes.

Most basidiomycetes form a fruiting body (mushroom) as part of their usual life cycle. The cell walls of the fruiting body are constructed mainly from chitin and $\beta$ glucans, and these polysaccharides are self-degraded by enzymes associated with cell walls during morphological changes (Shida et al. 1981; Minato et al. 2004). Recently, we reported identification of four $\beta$-1,3-glucanases (EXG1, EXG2, TLG1 and GLU1) and one $\beta$-1,6-glucanase (LePus30A) from the Lentinula edodes fruiting body, the shiitake mushroom (Sakamoto et al. 2005a; 2005b; 2006; 2011; Konno and Sakamoto 2011). While enzymes involved in cell wall metabolism of $L$. edodes have been reported only for those acting on $\beta$-glucan, the presence of chitinolytic enzymes were suggested in our previous study (Sakamoto et al. 2009). In the present study, we purified and characterized a $\beta$ - $N$-acetylhexosaminidase, LeHex20A, from the fruiting body of $L$. edodes.

\section{Materials and methods Materials}

L. edodes cultivated dikaryotic strain H600 (Hokken. Co., Ltd) was used in all experiments (Sakamoto et al., 2005a). Fruiting bodies for RNA and protein extraction were prepared using the method of Nagai et al. (2003). Mature fruiting bodies were separated into pileus, gill and stipe. Harvested mature fruiting bodies were immediately transferred to a desiccator at $25^{\circ} \mathrm{C}$ and $80 \%$ humidity for post-harvest preservation. All samples were stored at $-80^{\circ} \mathrm{C}$

Colloidal chitin was prepared according to Hsu and Lockwood (1975). Mechanochemically ground chitin was kindly provided by the Department of Chemical Engineering, Ichinoseki National College of Technology (Nakagawa et al. 2011).

\section{Purification of $\mathrm{\beta}-\mathrm{N}$-acetylhexosaminidase}

Proteins were extracted from $320 \mathrm{~g}$ of fresh fruiting bodies. Samples were crushed in liquid nitrogen, suspended in $320 \mathrm{ml}$ of $10 \mathrm{mM}$ sodium phosphate buffer ( $\mathrm{pH} 7.0)$, and incubated with rotation for $30 \mathrm{~min}$ at room temperature. Ammonium sulfate was added until the concentration reached $70 \%$ saturation. The resulting precipitates were collected by centrifugation $(30 \mathrm{~min}$, $4,500 \times g$ ) and dissolved in $10 \mathrm{mM}$ sodium phosphate buffer ( $\mathrm{pH}$ 7.0) containing ammonium sulfate at $30 \%$ saturation. The supernatant was applied to a PhenylToyopearl column $(1.6 \times 10 \mathrm{~cm}$, Tosoh Co., Ltd., Tokyo, Japan) equilibrated with $10 \mathrm{mM}$ sodium phosphate buffer ( $\mathrm{pH}$ 7.0) containing ammonium sulfate at $30 \%$ saturation. The column was washed with $45 \mathrm{ml}$ of the same buffer, and proteins were eluted in $45 \mathrm{ml}$ of a linear concentration gradient (30-0\% saturation) of ammonium sulfate at a flow rate of $1.5 \mathrm{ml} / \mathrm{min}$. Fractions containing $\beta$ - $N$-acetylhexosaminidase activity were collected and concentrated using an Amicon Ultra 5,000 NMWL filter (Millipore, Billerica, MA, USA), and then applied to a MonoQ 5/50 GL anion exchange column $(0.5 \times 5 \mathrm{~cm}$, GE Healthcare, Little Chalfont, UK). Adsorbed proteins were eluted using a linear concentration gradient of $\mathrm{NaCl}(0-0.5 \mathrm{M})$ at a flow rate of $0.5 \mathrm{ml} / \mathrm{min}$. The eluted enzyme was then applied to a DEAE-Toyopearl Pak $650 \mathrm{~S}$ anion exchange column $(0.8 \times 7.5 \mathrm{~cm}$, Tosoh Co., Ltd.) equilibrated with $10 \mathrm{mM}$ sodium phosphate buffer. The enzyme was eluted with a linear concentration gradient of $\mathrm{NaCl}(60 \mathrm{ml}, 0-0.5 \mathrm{M})$ at a flow rate of $0.5 \mathrm{ml} /$ min. Fractions containing activity were collected and concentrated. Concentrated proteins were then applied to a Superdex 75 10/30 gel filtration column (GE Healthcare) equilibrated in $10 \mathrm{mM}$ sodium phosphate buffer ( $\mathrm{pH} 7.0$ ) with $0.1 \mathrm{M} \mathrm{NaCl}$, and proteins were eluted with the same buffer at a flow rate of $0.4 \mathrm{ml} / \mathrm{min}$. Purified LeHex20A was analyzed by SDS-PAGE, and the $\mathrm{N}$-terminal amino acid sequence of LeHex20A was analyzed as described in Sakamoto et al. (2005a).

\section{Cloning and sequencing of the lehex20a gene}

cDNA was synthesized from total RNA extracted from fresh fruiting bodies using the SMART PCR RACE kit (BD Bioscience, CA, USA), according to the manufacturer's protocol. 3'-RACE was performed using degenerate primers (chi4-3U: 5'-ACN GYN GYN ATG GTN TGG AT-3' and chi4-4U: 5' -TGG TGY GAY CCN TTY AAR AC-3') designed against conserved amino acid sequences of GH family 20 in filamentous fungi. cDNA for the 5'-RACE PCR template was synthesized from the RNA using a GeneRacer kit (Invitrogen, CA, USA), and PCR was performed as described previously (Sakamoto et al., 2005b) using specific primers (chi4-56RACEL: 5' -AGT TTA GCT TGA GCA TCA GTC AAA T-3' and chi4-93-RACEL: 5'-CTC GGT CCA AAG TAG GTG TTC T-3') and GeneRacer primers (Invitrogen). The presence of a signal peptide in the deduced amino sequence was predicted using the SignalP server (http://www.cbs.dtu.dk/services/SignalP/). Comparative analysis of homology with enzymes registered in the GenBank databases was carried out using an NCBI 
BLAST search (http://www.ncbi.nlm.nih.gov/BLAST) with the default parameters.

\section{Enzyme assays}

$\beta$ - $N$-Acetylhexosaminidase activity was assayed in 20 $\mathrm{mM}$ sodium acetate buffer $(\mathrm{pH} 4.2)$ at $37^{\circ} \mathrm{C}$ for 15 min. For purification, activity was determined using $0.32 \mathrm{mM}$ of 4-methylumbelliferyl $\beta$-D- $N, N^{\prime}, N^{\prime \prime}$-triacetylchitotrioside (4MU-GlcNAc 3 , an analogue of the natural substrate, GlcNAc 4 ; Sigma-Aldrich Inc., St. Louis, MO, USA) as substrate (Hood 1991). The reaction was quenched with $0.4 \mathrm{M} \mathrm{Na} \mathrm{Na}_{2} \mathrm{CO}_{3}$, and the released 4MU was measured by spectrophotofluorimetry with excitation at $365 \mathrm{~nm}$ and emission at 445 $\mathrm{nm}$. The effects of $\mathrm{pH}$ ( $\mathrm{pH}$ 3-9) and temperature $\left(10-80^{\circ} \mathrm{C}\right)$ on enzyme activity were analyzed as described previously (Konno and Sakamoto 2011). To elucidate the substrate specificity of the enzyme, assays were performed using the following substrates: p-nitrophenyl- $N$-acetyl- $\beta$-D-glucosaminide (pNP-GlcNAc), p-nitrophenyl- $N$-acetyl-beta-D-galactosaminide (pNPGalNAc), p-nitrophenyl-D-glucoside (pNP-Glc) (SigmaAldrich), chitooligosaccharides, (GlcNAc 2 -6, Seikagaku Biobusiness Co., Tokyo, Japan), the complex N-glycan (GlcNAc $\beta-1,2$ Man $\alpha-1,6)($ GlcNAc $\beta-1,2 M a n \alpha-1,3)$ Man $\beta-1$ ,4GlcNAc $\beta-1,4$ GlcNAc-PA (TaKaRa Bio Inc., Shiga, Japan), chitin (Wako Pure Chemicals Co., Osaka, Japan), ethylene glycol chitin (Seikagaku kogyo, Co., Tokyo, Japan), colloidal chitin and the mechanochemically ground chitin. To assay pNP, the amount of pNP was determined spectrophotometrically at $405 \mathrm{~nm}$. The extinction coefficient of pNP was assumed to be $17,100 \mathrm{M}^{-1}$ $\mathrm{cm}^{-1}$. The amount of GlcNAc released from chitin oligomers and polymers was determined by the Morgan-Elson assay according to the method of Keyhani and Roseman (1996). One unit (U) of enzyme activity was defined as the amount of enzyme that produces $1 \mu \mathrm{mol}$ GlcNAc per minute under the above conditions. To determine the kinetic properties of LeHex20A, the reactions were performed with $0.05-0.5 \mathrm{mM}$ of substrate and $3.1 \mathrm{nM}$ of purified LeHex20A in $20 \mathrm{mM}$ sodium acetate buffer $(\mathrm{pH} 4.2)$ at $37^{\circ} \mathrm{C}$ for $15 \mathrm{~min}$. In these reactions, the products formed from the chitooligosaccharides $\left(\mathrm{GlNNAc}_{2-6}\right)$ were monosaccharides (GlcNAc) and oligosaccharides shortened by one GlcNAc unit (HPLC analyses, data not shown). The values of $k_{\text {cat }}$ and $K_{\mathrm{m}}$ were estimated using LineweaverBurk plots.

\section{HPLC analysis}

To study the degradation of natural substrates, $2 \%(\mathrm{w} / \mathrm{v})$ amorphous chitins (colloidal chitin or mechanochemically grinded chitin) or $0.5 \mathrm{mM}$ chitooligosaccharides were incubated at $30{ }^{\circ} \mathrm{C}$ in $20 \mathrm{mM}$ sodium acetate buffer $(\mathrm{pH} 4.2)$, using $0.92 \mathrm{nM}$ purified LeHex20A for the chitins and $0.40 \mathrm{nM}$ LeHex20A for the chitooligosaccharides. The hydrolysis products were analyzed using an HPLC system equipped with a TSKgel Amide-80 column $(4.6 \times 250 \mathrm{~mm}$, Tosoh). The mobile phase was $65 \%$ $(\mathrm{v} / \mathrm{v})$ acetonitrile at a flow rate of $1.0 \mathrm{ml} / \mathrm{min}$, and the column temperature was $80^{\circ} \mathrm{C}$. Eluted carbohydrates were detected by monitoring UV absorption at $205 \mathrm{~nm}$.

\section{Nucleotide sequence accession number}

The nucleotide sequence encoding LeHex20A has been deposited in the DDBJ/EMBL/GenBank databases under the accession number [DDBJ: AB703443].

\section{Results}

\section{Purification of LeHex20A and cloning of its gene,} lehex20a

LeHex20A was purified from fresh fruiting bodies of $L$. edodes by four steps of column chromatography, with monitoring of activity towards $4 \mathrm{MU}-\mathrm{GlcNAc}_{3}$. As a result of the purification, a single major band was obtained by SDS-PAGE, and the deduced molecular mass of the purified LeHex20A was $79 \mathrm{kDa}$ (Figure 1). The $\mathrm{N}$-terminal amino acid sequence of the $79 \mathrm{kDa}$ protein was LWPLPTDFSTGTAAL, which was highly similar to the N-terminal amino acid sequence of GH family 20 (GH20) members in filamentous fungi. Because amplification by 3 '-RACE PCR using primers designed based on the Nterminal sequence was unsuccessful, we designed degenerate primers based on the conserved amino acid sequence of GH20 members in filamentous fungi. We succeeded in amplifying a DNA fragment by 3 '-RACE PCR, which contained a highly similar sequence to other GH20 members. Following 5'-RACE, we obtained full-length sequence for lehex20a, which contained a putative N-terminal amino acid sequence identical to the LeHex20A N-terminus. The cDNA contained an open reading frame of $1,659 \mathrm{bp}$, encoding 553 amino acid residues.

According to the results of SignalP analysis, the first 17 amino acid residues in the $\mathrm{N}$-terminal region are expected to be a signal peptide, indicating that the mature protein, consisting of 536 amino acids, is an extracellular or cell wall protein. LeHex20A has a calculated molecular mass of $58 \mathrm{kDa}$, suggesting that the protein is glycosylated. Indeed, the amino acid sequence had 13 possible $\mathrm{N}$-glycosylation sites (Asn-Xxx-Thr/Ser http:// www.cbs.dtu.dk/services/NetNGlyc/). In addition, there were many possible sites for O-glycosylation (http:// www.cbs.dtu.dk/services/NetOGlyc/). The sequence was analyzed using searches on the Pfam database (http:// pfam.sanger.ac.uk/search/sequence). Search results for the sequence showed that the amino acid sequence contains GH20 domains. The deduced amino acid sequence was analyzed using the blastp algorithm of the NCBI protein database. The BLAST search showed that the 


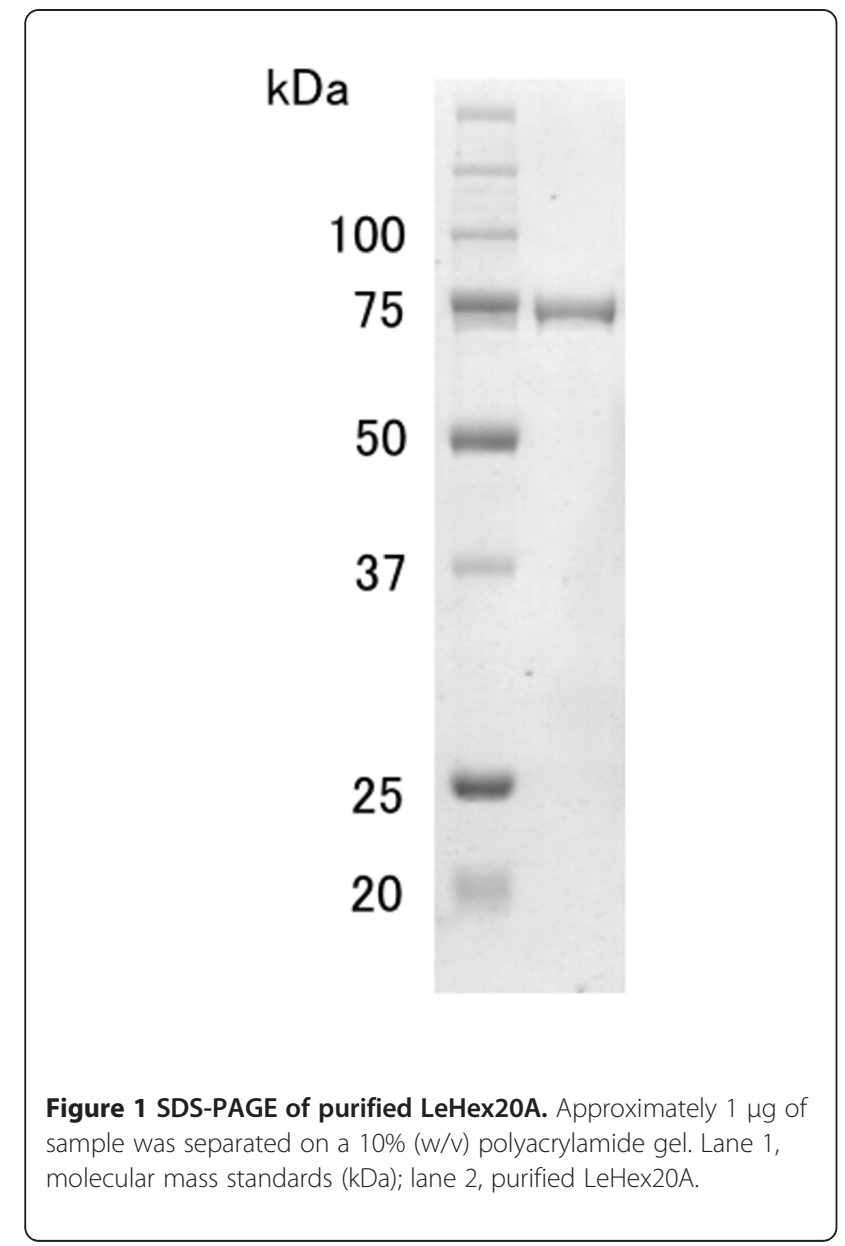

sequence had up to $61 \%$ sequence identity to putative GH20 proteins (containing putative $\beta-N$-acetylhexosaminidase sequences) from basidiomycetous species such as Serpula lacrymans (EGN97893), Coprinopsis cinerea (XP_001835638) and Postia placenta (XP_002472465). The sequence showed homology to putative GH20 proteins from ascomycetes such as Leptosphaeria maculans (CBX95932) and Trichoderma reesei (EGR50812), although in these cases, sequence identity levels were only about 30\%. These results suggest that LeHex20A belongs to GH20. Further sequence analyses were carried out using the blastp algorithm in genome sequence databases of basidiomycetes (http://genome.jgi-psf.org/programs/fungi/index.jsf). These searches revealed that LeHex20A has high levels of similarity to proteins of basidiomycetes including Fomitopsis pinicola (ID number from DOE Joint Genome Institute, 129075; similarity, 61\%), Heterobasidion annosum (151266; 58\%), Agaricus bisporus (120598; 58\%) and Pleurotus ostreatus (57387/87509; 58\%). Thus, homologues of lehex20a seem to be conserved in basidiomycetes.

\section{Enzymatic properties of LeHex20A}

Effects of $\mathrm{pH}$ and temperature on enzyme activity were examined using 4MU-GlcNAc 3 as a substrate. The maximum LeHex20A activity was observed at $\mathrm{pH} 4.0$ in 20 $\mathrm{mM}$ sodium acetate buffer and at $50^{\circ} \mathrm{C}$. The enzyme was stable across a pH range from 5 to 8 when incubated at $4^{\circ} \mathrm{C}$ for $20 \mathrm{~h}$. The enzyme was inactivated after incubation at $60^{\circ} \mathrm{C}$ for $30 \mathrm{~min}$.

Substrate specificity of the purified LeHex20A was estimated. In pNP-substrate assays, LeHex20A showed hydrolytic activity for not only pNP-GlcNAc, but also pNP-GalNAc, and no activity was detected for pNP-Glc. These results indicate that LeHex20A is a $\beta$ - $N$-acetylhexosaminidase classified into EC 3.2.1.75. While some $\beta-N$-acetylhexosaminidases also cleave $\beta-1,2$ linkages in complex $\mathrm{N}$-glycan substrates, resulting in liberation of terminal GlcNAc, LeHex20A had no activity for this type of substrate. When pNP-GlcNAc, pNP-GalNAc and chitooligosaccharides $\left(\mathrm{GlcNAc}_{2-6}\right)$ were used as substrates, the kinetic constants, $k_{\text {cat }} / K_{\mathrm{m}}$, were estimated as follows: $\quad \mathrm{GlcNAc}_{4}>\mathrm{GlcNAc}_{3}>\mathrm{GlcNAc}_{5}>\mathrm{GlcNAc}_{6}>$ pNP-GlcNAc $>$ GlcNAc $_{2}>$ pNP-GalNAc (Table 1). LeHex20A had high $k_{\text {cat }}$ toward short-chain substrates, such as pNP-GlcNAc and GlcNAc 2 . The $k_{\text {cat }}$ value for $\mathrm{GlcNAc}_{2}$ was 2.0-fold than for $\mathrm{GlcNAc}_{4}$ and 2.5-fold higher than for $\mathrm{GlcNAc}_{6}$. In contrast, the enzyme showed higher affinity for the longer-chain chitooligosaccharides: the $K_{\mathrm{m}}$ value for $\mathrm{GlcNAc}_{4}$ was 5.4-fold lower than for $\mathrm{GlcNAc}_{2}$ and $\mathrm{GlcNAc}_{6}$ was 3.9-fold lower.

LeHex20A activities for chitin polysaccharides including crystalline chitin, colloidal chitin, mechanochemically ground chitin and ethylene glycol chitin were examined. No activity was detected for crystalline chitin or ethylene glycol chitin. LeHex20A partially hydrolyzed colloidal chitin and mechanochemically ground chitin, although original insoluble chitin accumulated even after a long incubation with the enzyme. The specific activities determined by the rate of monomer production were $46.3 \mathrm{U} /$ mg for colloidal chitin and $39.9 \mathrm{U} / \mathrm{mg}$ for mechanochemically ground chitin. To elucidate LeHex20A action against colloidal chitin, the supernatant in each reaction mixture was analyzed using HPLC (Figure 2). Chromatograms of samples at the start of the reaction showed the presence of various oligomers in the colloidal chitin, and these oligomers disappeared after 3 hours, accompanied by production of GlcNAc. In chromatograms of $12 \mathrm{~h}$ samples, more GlcNAc was produced as the reaction product. A similar result was obtained upon analyzing reaction products obtained from mechanochemically ground chitin (data not shown). These observations suggest that LeHex20A has exochitinase activity against amorphous chitin polysaccharides. 
Table 1 Kinetic parameters of LeHex20A

\begin{tabular}{llll}
\hline Substrate & $\boldsymbol{K}_{\mathbf{m}}(\mathbf{m M})$ & $\boldsymbol{k}_{\text {cat }}(\mathbf{s}-\mathbf{1})$ & $\boldsymbol{k}_{\text {cat }} / \boldsymbol{K}_{\mathbf{m}}$ \\
\hline pNP-GIcNAc & $0.34 \pm 0.01$ & $335 \pm 10$ & 983 \\
pNP-GalNAc & $0.43 \pm 0.03$ & $177 \pm 8$ & 411 \\
Chitobiose(DP2) & $0.42 \pm 0.04$ & $242 \pm 14$ & 576.7 \\
Chitotriose(DP3) & $0.14 \pm 0.001$ & $236 \pm 1$ & 1667 \\
Chitotetraose(DP4) & $0.07 \pm 0.008$ & $119 \pm 5$ & 1689 \\
Chitopentaose(DP5) & $0.08 \pm 0.001$ & $97 \pm 1$ & 1190 \\
Chitohexaose(DP6) & $0.1 \pm 0.002$ & $97 \pm 1$ & 992 \\
\hline
\end{tabular}

\section{Discussion}

Knowledge of chitinolytic enzymes from basidiomycetes is important because these enzymes are likely to play roles on the autolysis of cell-wall chitin, which may result in morphological changes and affect the product quality of fruiting bodies (Kamada et al. 1982; Kües 2000; Mitchell and Sabar 1966; Sakamoto et al. 2009; Sone and Misaki 1978). Nevertheless, little is known about chitinolytic enzymes from basidiomycetes. In this study, we purified a protein with $\beta$ - $N$-acetylhexosaminidase activity from fresh $L$. edodes fruiting bodies, and

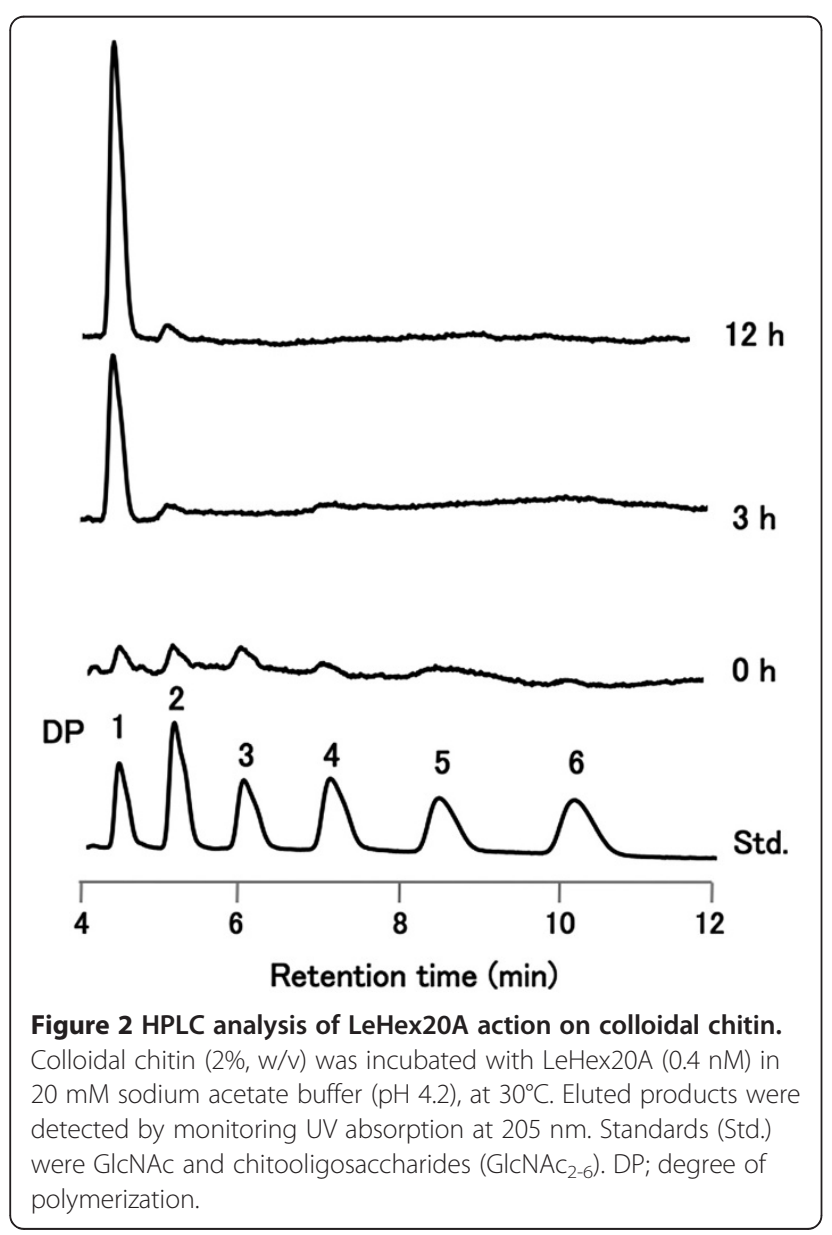

the analysis of its primary structure showed that the enzyme belongs to GH20. Therefore, we named the protein LeHex20A. To the best of our knowledge, this is the first report of a gene encoding a GH20 $\beta$ - $N$-acetylhexosaminidase from basidiomycetes.

GH20 enzymes are retaining GHs and have catalytic domains with a $(\beta / \alpha)_{8}$ (TIM barrel) fold (Tews et al. 1996). The enzymes carry out substrate-assisted catalysis, in which a glutamate (Glu303 in LeHex20A; Figure 3) acts as the catalytic acid/base and the acetamido group of the sugar bound at the -1 subsite acts as a nucleophile (Drouillard et al. 1997; Jones and Kosman 1980). A conserved Asp adjacent to the catalytic acid (Asp302 in LeHex20A) is crucial for activating the acetamido group (Williams et al. 2002). While this catalytic dyad is conserved in LeHex20A, the consensus H-x-G-G motif, preceding the catalytic residue of representative $\mathrm{GH} 20$ members from bacteria, plant, insects, mammals, and ascomycetes, is not conserved in LeHex20A (Intra et al. 2008; Mayer et al. 2006). In LeHex20A and other basidiomycetes including S. lacrymans, C. cinerea, P. placenta, F. pinicola, $H$. annosum, $A$. bisporus and $P$. ostreatus, this motif has the sequence $\mathrm{S}-\mathrm{x}-\mathrm{G}-\mathrm{G}$, a sequence that seems unique for basidiomycete $\mathrm{GH} 20$ enzymes.

Most of the GH20 $\beta$ - $N$-acetylhexosaminidases have the highest catalytic efficiency for $\mathrm{GlcNAc}_{2}$ among natural substrates, and do not hydrolyze long-chain chitomaterials (Keyhani and Roseman 1996; Koga et al. 1996; Ueda and Arai 1992; Yang et al. 2008). However, the catalytic efficiency of LeHex20A for GlcNAc $_{6}$ was greater than for $\mathrm{GlcNAc}_{2}$, due to its high affinity for $\mathrm{GlcNAc}_{6}$. Moreover, the enzyme partially hydrolyzed two kinds of amorphous chitin polymers, resulting in production of GlcNAc. There are few reports about degradation of chitin polymers by $\beta$ - $N$-acetylhexosaminidases (Suginta et al. 2010). Indeed, only six $\beta$ - $N$-acetylhexosaminidases (EC 3.2.1.52) that are able to degrade chitin polymer are listed in the BRENDA database (http://www. brenda-enzymes.info/index.php4). Thus, LeHex20A showed unique enzymatic properties with respect to typical GH20 $\beta$ - $N$-acetylhexosaminidases. Because $\beta-N$ acetylhexosaminidases hydrolyze nonreducing terminal monosaccharide residues of substrates, binding between the subsite $(-1)$ of the enzymes and the nonreducing terminal $\beta-N$-acetylhexosaminides of substrates seems to be essential for the catalysis. Suginta et al. (2010) reported that GH20 $\beta$-N-acetylhexosaminidases from the bacterium Vibrio harveyi show hydrolytic activity toward colloidal chitin, and suggested that the enzyme has a binding pocket containing four GlcNAc binding subsites. Therefore, LeHex20A might have other GlcNAc binding subsites, as suggested for this protein by Suginta et al. 


LeHexA
Hypocrea
Aspergillus
Ostrinia
Homo
Arabidopsis
Streptomyces

NANTTNFTASLISS-VSARFP-GKYF STGGDELNTECYAIDESTQADLNTT-----GKTL DSKVYDFVDKLFDDLLPRVT PYSSY FHTGGDELNAN----DSMI DPRYKSN----SSDVL YNKTYEVVGNVYKE-LSDIFP-DHWF HVGGDEIQPNCFNFSTHVTKWFAED----PSRTY KDELYQYLEDIYSD-MAEVFDTTDI HMGGDEVSEACWNSSDSIQNFMMQNRWDLDKESF LNNTYEFMSTFFLE-VSSVFP-DFYI HLGGDEVDFTCWKSNPEIQDFMRKKGF---GEDF KNFTFDVISGILAD-MRKIFP-FELEHLGGDEVNTDCWKNTTHVKERLQGR-----NFTT KDVTYDFVDDVIGE-LAALTP-GRYL HIGGDEAHS-----------------TP

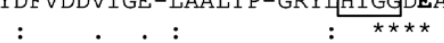

Figure 3 Multiple sequence alignment of a region surrounding the catalytic residue of GH family 20 members ( $\beta-N$ acetylhexosaminidases) from Lentinula edodes (LeHex20A), Hypocrea lixii (AAB50829), Aspergillus oryzae (XP_001817681), Ostrinia furnacalis (ABI81756), Homo sapiens (AAB00965), Arabidopsis thaliana (BAE99290) and Streptomyces plicatus (AAC38798). Protein sequences were aligned with the MAFFT program (version 6; http://align.bmr.kyushu-u.ac.jp/mafft/online/server/) using the E-INS-I algorithm. A consensus motif preceding the catalytic residue is boxed. The catalytic glutamate is bold.

As described in this report, LeHex20A can produce GlcNAc from longer-chain chitomaterials compared with typical $\beta-N$-acetylhexosaminidases. Moreover, the L. edodes fruiting body, the shiitake mushroom, is a very popular edible cultivated mushroom. Therefore, LeHex20A may be valuable for efficient and safe enzymatic production of GlcNAc from native chitin materials.

\section{Competing interests}

The authors declare that they have no competing interests.

\section{Acknowledgments}

We thank to Miss Ayumi Obara for her help with experiments. We are grateful to Vincent G H Eijsink of Norwegian University of Life Sciences for his suggestion and comments. We also thank to Kazuhide Totani, Mitsuru Nikaido, Yuko S. Nakagawa of the Department of Chemical Engineering, Ichinoseki National College of Technology, who provide us mechanochemically ground chitin.

This research was supported by a Grant-in-Aid for Scientific Research to N.K. (no. 23780169) from the Japan Society for the Promotion of Science (JSPS), and Grants for project research (Development of fundamental technology for analysis and evaluation of functional agricultural products and functional foods).

Received: 1 May 2012 Accepted: 13 May 2012

Published: 1 June 2012

\section{References}

Brurberg MB, Nes IF, Eijsink VG (1996) Comparative studies of chitinases A and B from Serratia marcescens. Microbiology 142:1581-1589

Cannon RD, Niimi K, Jenkinson HF, Shepherd MG (1994) Molecular cloning and expression of the Candida albicans $\beta$-N-acetylglucosaminidase (HEX1) gene. J Bacteriol 176:2640-2647

Carsolio C, Gutiérrez A, Jiménez B, Van Montagu M, Herrera-Estrella A (1994) Characterization of ech-42, a Trichoderma harzianum endochitinase gene expressed during mycoparasitism. Proc Natl Acad Sci U S A 91:10903-10907

Clarke VA, Platt N, Butters TD (1995) Cloning and expression of the $\beta-N$ acetylglucosaminidase gene from Streptococcus pneumoniae. Generation of truncated enzymes with modified aglycon specificity. J Biol Chem 270:8805-8814

Drouillard S, Armand S, Davies GJ, Vorgias CE, Henrissat B (1997) Serratia marcescens chitobiase is a retaining glycosidase utilizing substrate acetamido group participation. Biochem J 328:945-949

Hogenkamp DG, Arakane Y, Kramer KJ, Muthukrishnan S, Beeman RW (2008) Characterization and expression of the $\beta$ - $N$-acetylhexosaminidase gene family of Tribolium castaneum. Insect Biochem Mol Biol 38:478-489

Hood MA (1991) Comparison of four methods for measuring chitinase activity and the application of the 4-MUF assay in aquatic environments. J Microbiol Methods 13:151-160

Hsu SC, Lockwood JL (1975) Powdered chitin agar as a selective medium for enumeration of actinomycetes in water and soil. Appl Microbiol 29:422-426
Intra J, Pavesi G, Horner DS (2008) Phylogenetic analyses suggest multiple changes of substrate specificity within the glycosyl hydrolase 20 family. BMC Evol Biol 8:214

Iten W, Matile P (1970) Role of chitinase and other lysosomal enzymes of Coprinus Zagopus in the autolysis of fruiting bodies. J Gen Microbiol 61:301-309

Jones CS, Kosman DJ (1980) Purification, properties, kinetics, and mechanism of $\beta$-N-acetylglucosamidase from Aspergillus niger. J Biol Chem 255:11861-11869

Kamada T, Hamada Y, Takemaru T (1982) Autolysis in vitro of the stipe cell wall in Coprinus macrorhizus. Microbiology 128:1041-1046

Keyhani NO, Roseman S (1996) The chitin catabolic cascade in the marine bacterium Vibrio furnissii. Molecular cloning, isolation, and characterization of a periplasmic $\beta$ - $N$-acetylglucosaminidase. J Biol Chem 271:33425-33434

Kim S, Matsuo I, Ajisaka K, Nakajima H, Kitamoto K (2002) Cloning and characterization of the nagA gene that encodes $\beta$ - $N$-acetylglucosaminidase from Aspergillus nidulans and its expression in Aspergillus oryzae. Biosci Biotechnol Biochem 66:2168-2175

Koga D, Hoshika H, Matsushita M, Tanaka A, Ide A, Kono M (1996) Purification and characterization of $\beta-N$-acetylhexosaminidase from the liver of a prawn, Penaeus japonicus. Biosci Biotechnol Biochem 60:194-199

Konno N, Sakamoto Y (2011) An endo- $\beta$-1,6-glucanase involved in Lentinula edodes fruiting body autolysis. Appl Microbiol Biotechnol 91:1365-1373

Korneluk RG, Mahuran DJ, Neote K, Klavins MH, O'Dowd BF, Tropak M, Willard HF, Anderson MJ, Lowden JA, Gravel RA (1986) Isolation of CDNA clones coding for the a-subunit of human $\beta$-hexosaminidase. J Biol Chem 261:8407-8413

Kües U (2000) Life history and developmental processes in the basidiomycete Coprinus cinereus. Microbiol Mol Biol Rev 64:316-353

López-Mondéjar R, Catalano V, Kubicek CP, Seidl V (2009) The $\beta-N$ acetylglucosaminidases NAG1 and NAG2 are essential for growth of Trichoderma atroviride on chitin. FEBS J 276:5137-5148

Mark BL, Vocadlo DJ, Knapp S, Triggs-Raine BL, Withers SG, James MN (2001) Crystallographic evidence for substrate-assisted catalysis in a bacterial $\beta$ hexosaminidase. J Biol Chem 276:10330-10337

Mayer C, Vocadlo DJ, Mah M, Rupitz K, Stoll D, Warren RA, Withers SG (2006) Characterization of a $\beta-N$-acetylhexosaminidase and a $\beta-N$ acetylglucosaminidase/ $\beta$-glucosidase from Cellulomonas fimi. FEBS $J$ 273:2929-2941

Meli VS, Ghosh S, Prabha TN, Chakraborty N, Chakraborty S, Datta A (2010) Enhancement of fruit shelf life by suppressing $N$-glycan processing enzymes. Proc Natl Acad Sci U S A 107:2413-2418

Minato K, Kawakami S, Nomura K, Tsuchida H, Mizuno M (2004) An exo $\beta-1,3$ glucanase synthesized de novo dgrades lentinan during storage of Lentinula edodes and diminishes immunomodulationg activity of the mushroom. Carbohydr Polym 56:279-286

Mitchell R, Sabar N (1966) Autolytic enzymes in fungal cell walls. J Gen Microbiol 42:39-42

Nagai M, Kawata M, Watanabe H, Ogawa M, Saito K, Takesawa T, Kanda K, Sato T (2003) Important role of fungal intracellular laccase for melanin synthesis: purification and characterization of an intracellular laccase from Lentinula edodes fruit bodies. Microbiology 149:2455-2462

Nakagawa YS, Oyama Y, Kon N, Nikaido M, Tanno K, Kogawa J, Inomata S, Masui A, Yamamura A, Kawaguchi M, Matahira Y, Totani K (2011) Development of innovative technologies to decrease the environmental burdens associated 
with using chitin as a biomass resource: mechanochemical grinding and enzymatic degradation. Carbohydr Polym 83:1843-1849

Peterbauer CK, Lorito M, Hayes CK, Harman GE, Kubicek CP (1996) Molecular cloning and expression of the nag 1 gene ( $N$-acetyl- $\beta$-D-glucosaminidaseencoding gene) from Trichoderma harzianum P1. Curr Genet 30:325-331

Rast DM, Horsch M, Furter R, Gooday GW (1991) A complex chitinolytic system in exponentially growing mycelium of Mucor rouxii: properties and function. J Gen Microbiol 137:2797-2810

Sakamoto Y, Irie T, Sato T (2005a) Isolation and characterization of a fruiting body-specific exo- $\beta-1,3-$ glucanase-encoding gene, exg1, from Lentinula edodes. Curr Genet 47:244-252

Sakamoto Y, Minato K, Nagai M, Kawakami S, Mizuno M, Sato T (2005b) Characterization of the Lentinula edodes exg2 gene encoding a lentinan-

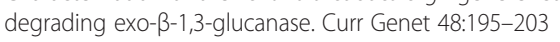

Sakamoto Y, Watanabe H, Nagai M, Nakade K, Takahashi M, Sato T (2006) Lentinula edodes $\operatorname{tg} 1$ encodes a thaumatin-like protein that is involved in lentinan degradation and fruiting body senescence. Plant Physiol 141:793-801

Sakamoto Y, Nakade K, Sato T (2009) Characterization of the post-harvest changes in gene transcription in the gill of the Lentinula edodes fruiting body. Curr Genet 55:409-423

Sakamoto Y, Nakade K, Konno N (2011) Endo- $\beta-1,3-g$ lucanase GLU1, from the fruiting body of Lentinula edodes, belongs to a new glycoside hydrolase family. Appl Environ Microbiol 77:8350-8354

Seidl V, Druzhinina IS, Kubicek CP (2006) A screening system for carbon sources enhancing $\beta$ - $N$-acetylglucosaminidase formation in Hypocrea atroviridis (Trichoderma atroviride). Microbiology 152:2003-2012

Seiler S, Plamann M (2003) The genetic basis of cellular morphogenesis in the filamentous fungus Neurospora crassa. Mol Biol Cell 14:4352-4364

Shida M, Ushioda Y, Nakajima T, Matsuda K (1981) Structure of the alkali-insoluble skeletal glucan of Lentinus edodes. J Biochem 90:1093-1100

Shin KS, Kwon NJ, Kim YH, Park HS, Kwon GS, Yu JH (2009) Differential roles of the ChiB chitinase in autolysis and cell death of Aspergillus nidulans. Eukaryot Cell 8:738-746

Sone Y, Misaki A (1978) Purification and characterization of $\beta$-D-mannosidase and $\beta$ - $N$-acetyl-D-hexosaminidase of Tremella fuciformis. J Biochem 83:1135-1144

Suginta W, Chuenark D, Mizuhara M, Fukamizo T (2010) Novel $\beta-N$ acetylglucosaminidases from Vibrio harveyi 650: cloning, expression, enzymatic properties, and subsite identification. BMC Biochem 11:40

Tanaka T, Fukui T, Imanaka T (2001) Different cleavage specificities of the dual catalytic domains in chitinase from the hyperthermophilic archaeon Thermococcus kodakaraensis KOD1. J Biol Chem 276:35629-35635

Tews I, Perrakis A, Oppenheim A, Dauter Z, Wilson KS, Vorgias CE (1996) Bacterial chitobiase structure provides insight into catalytic mechanism and the basis of Tay-Sachs disease. Nat Struct Biol 3:638-648

Ueda M, Arai M (1992) Purification and some properties of $\beta-N$ Acetylglucosaminidase from Aeromonas sp. 105-24. Biosci Biotechnol Biochem 56:1204-1207

Vetter J (2007) Chitin content of cultivated mushrooms Agaricus bisporus, Pleurotus ostreatus and Lentinula edodes. Food Chem Volume 102:6-9

Williams SJ, Mark BL, Vocadlo DJ, James MN, Withers SG (2002) Aspartate 313 in the Streptomyces plicatus hexosaminidase plays a critical role in substrateassisted catalysis by orienting the 2-acetamido group and stabilizing the transition state. J Biol Chem 277:40055-40065

Yang Q, Liu T, Liu F, Qu M, Qian X (2008) A novel B-N-acetyl-D-hexosaminidase from the insect Ostrinia furnacalis (Guenée). FEBS J 275:5690-5702

doi:10.1186/2191-0855-2-29

Cite this article as: Konno et al:: Characterization of $\beta-N-$

acetylhexosaminidase (LeHex20A), a member of glycoside hydrolase family 20, from Lentinula edodes (shiitake mushroom). AMB Express 2012 2:29.

Submit your manuscript to a SpringerOpen ${ }^{\odot}$ journal and benefit from:

- Convenient online submission

- Rigorous peer review

- Immediate publication on acceptance

- Open access: articles freely available online

- High visibility within the field

- Retaining the copyright to your article

Submit your next manuscript at $\gg$ springeropen.com 